This item was submitted to Loughborough's Research Repository by the author.

Items in Figshare are protected by copyright, with all rights reserved, unless otherwise indicated.

\title{
Critical alignment in inquiry-based practice in developing mathematics teaching
}

PLEASE CITE THE PUBLISHED VERSION

http://dx.doi.org/10.1007/s10649-013-9489-z

\section{PUBLISHER}

(C) Springer Science + Business Media

\section{VERSION}

SMUR (Submitted Manuscript Under Review)

\section{PUBLISHER STATEMENT}

This work is made available according to the conditions of the Creative Commons Attribution-NonCommercialNoDerivatives 4.0 International (CC BY-NC-ND 4.0) licence. Full details of this licence are available at: https://creativecommons.org/licenses/by-nc-nd/4.0/

\section{LICENCE}

CC BY-NC-ND 4.0

\section{REPOSITORY RECORD}

Goodchild, Simon, Anne Berit Fuglestad, and Barbara Jaworski. 2019. "Critical Alignment in Inquiry-based Practice in Developing Mathematics Teaching”. figshare. https://hdl.handle.net/2134/18203. 


\section{Title Page}

Simon Goodchild Anne Berit Fuglestad Barbara Jaworski

University of Agder University of Agder Loughborough University

Critical alignment in inquiry-based practice in developing mathematics teaching.

Fuglestad and Goodchild

University of Agder,

Postbox 422,

4604 Kristiansand, Norway

Jaworski

Loughborough University, UK

Mathematics Education Centre

Loughborough

LE11 3TU,

UK

Corresponding author:

Anne Berit Fuglestad, University of Agder,

e-mail: Anne.B.Fuglestad@uia.no

$\mathrm{Tel}+4738141538$

Fax +4738141071

Submission: EDUC1513

Revised paper 


\title{
Critical alignment in inquiry-based practice in developing mathematics teaching.
}

\author{
Simon Goodchild Anne Berit Fuglestad Barbara Jaworski \\ University of Agder, Norway Loughborough University, UK
}

\begin{abstract}
This paper reports a case study from a mathematics teaching developmental research project. The theoretical foundation for the research comprises communities of inquiry and critical alignment, with which the developmental methodology has a particular synergy. This synergy is the main focus of the paper. The paper elaborates theoretical and methodological antecedents of the project and traces these through a case study of developments in the practices of one upper secondary school team and a group of university didacticians (mathematics teacher educators and researchers) during the first year of the project. The case study reveals that critical alignment and inquiry (necessarily) bring uncertainty and risk, and foster tensions within the teachers' practice and between the practices of teachers and didacticians. In exposing these uncertainties, risks and tensions the paper points to their value for the learning and knowledge gained by participants.
\end{abstract}

\section{Keywords}

learning community, inquiry, co-learning, mathematics teaching development, developmental research

\section{Introduction}

The authors of this paper were didacticians (mathematics educator-researchers) in a developmental research project in Norway whose aim was to work with teachers in a range of schools to promote development of mathematics teaching in classrooms and to study this development. The project, Learning Communities in Mathematics (LCM), took place over four years which included three years of fieldwork between didacticians and teachers in eight schools. Didacticians established the project, in terms of its aims, theoretical base and 
methodology, with funding from the Research Council of Norway ${ }^{1}$. A principal aim was to work with teachers as co-learning professionals, with didacticians and teachers each contributing specialist knowledge and together developing new knowledge in practice (Schön, 1987; Wagner, 1997).

An aim for both groups was that students should enjoy, understand and become proficient in mathematics; three dimensions for students' learning. Teachers engaged in practice in their schools to achieve this aim, but were not always satisfied with the outcomes, as we shall show. One of the main reasons for joining the project was their desire to improve their students' opportunities to learn. Schools were invited to join: those who accepted the invitation agreed that three or more teachers would take part and that the school would be supportive of the project. Funding was provided for the teachers to attend project meetings. As didacticians we wanted to work with teachers to reflect on current practices and to consider possibilities for development. We based our work theoretically on the creation of communities of inquiry and critical alignment, with which our developmental methodology has a particular synergy as we will explain. This synergy is the main focus of our paper. We elaborate the theoretical and methodological antecedents and trace these through a case study of developments in practice, revealing learning and knowledge gained from our research.

\section{A methodological and theoretical synergy}

Developmental research (Gravemeijer,1994) can be applied to many types of educational activity, from curriculum development to micro designs of tasks and activities within lessons. In this paper we designate as ‘developmental research' a collaborative partnership between teachers and didacticians that set out with the goal to improve students' experience of mathematics through developing teaching. In this section we set the project in the context of one strand of developmental research. Next, community of practice theory, and a local theory of inquiry are outlined as the framework within which teaching and developmental activity are conceptualised. We then provide a methodological model of teaching developmental research and end the section with an account of how the model was implemented within the project.

\subsection{Development and research as dialectical processes}

Traditionally, in mathematics education, development and research have been seen as different processes. Teacher education programmes, whether for prospective or for practising

\footnotetext{
${ }^{1}$ Learning Communities in Mathematics, project no. 157949/S20
} 
teachers, have been developmental programmes in which practices have been encouraged according to theoretical visions offered by teacher educators and aimed at the practice of teachers (Even, 2008; Jaworski, 2011). If such programmes have been researched, then research has studied the processes and outcomes of the programmes and reported on what the programmes achieved and the issues they raised (Llinares \& Krainer, 2006). In the later 1980s and the 1990s in mathematics education, practitioner research grew as a developmental paradigm in mathematics teaching-learning (Zack, Mousley, \& Breen, 1997). Here practitioners are both teachers and teacher-educators (or didacticians), both of whom engage in research into their own practices with a view to learning how to undertake the practice more effectively.

Developmental research between teachers and didacticians builds on ideas of practitioner research and promotes development simultaneously with studying the developmental process. In such a project, development and research act dialectically, developmental actions generate data for analysis in the research, and processes of data generation provide developmental opportunities; all participants are central players sharing action and outcome. Practitioner inquiry, insider research, where insiders are those researching their own practice, results in knowledge in practice; more formal research, outsider research, where outsiders are those who research the practices of others, results in knowledge about practice. Insider research leads to more overt knowledge in practice through which practice can improve. Outsider research leads to more generalised knowledge available for inspection and critique in the academic community (Jaworski, 2003).

\subsection{Collaboration in communities of practice}

Collaboration between teachers and didacticians may be conceptualised in terms of Communities of Practice (CoP) (Wenger, 1998). We may speak of a social group as a community, a group of people identifiable by who they are in terms of how they relate to each other, their common activities and ways of thinking, beliefs and values. Activities are likely to be explicit, whereas ways of thinking, beliefs and values are more implicit. Wenger (1998) describes community as "a way of talking about the social configurations in which our enterprises are defined as worth pursuing and our participation is recognisable as competence” (p. 5). "The social configurations in which our enterprises are defined" are the basis of practice. Wenger writes further,

The concept of practice connotes doing, but not just doing in and of itself. It is doing in a historical and social context that gives structure and meaning to what we do. In this sense practice is always social practice. (p. 47) 
The activity of teacher and students engaging with mathematics within an institutional setting can be seen as a practice; teaching itself can be seen as a practice in which teachers engage; similarly didacticians' engagement in university practices or in working with teachers. According to Wenger, (1998, pp. 173ff.) belonging to a CoP, or having identity within a CoP, involves engagement, imagination and alignment. Thus, in practices of mathematics learning and teaching, participants engage in their practice alongside their peers, use imagination in interpreting their own roles in the practice and align themselves with established norms and values.

\subsection{Communities of inquiry and critical alignment}

The growth of communities of practice is a dialectical process between the engagement of individuals exercising imagination in alignment and the norms and expectations of the communal practice. There are many ways of seeing such growth. For example, Brown and McIntyre (1993) characterise teaching-learning in school classrooms as settling down to "normal desirable states” in which teachers and students have developed ways of being, ways of working together, that are mutually enabling but often not cognitively challenging. The outsider researcher, at a distance from the practice, can make such observations or judgment, while the insiders are limited by their visions in engagement and alignment.

In contrast, the overt use of inquiry in practice has the aim of disturbing practice on the inside, of challenging the status quo, of questioning accepted ways of being and doing. Inquiry is about asking questions and seeking answers, recognising problems and seeking solutions, exploring and investigating to find out more about what we do that can help us do it better. Such use of inquiry starts off as a mediating tool in the practice (for example, an inquirybased task is used as a tool to engage students in mathematical thinking), and shifts over time to become an inquiry stance or an inquiry way of being in practice (when teachers and/or students become 'inquirers' as one of the norms of practice) (Cochran-Smith \& Lytle, 1999; Jaworski, 2004). Participants can develop an inquiry identity so that inquiry becomes a norm of practice with which to be aligned. Thus we might see the use of inquiry as a tool to be a form of critical alignment; that is engagement in and alignment with the practices of the community while at the same time asking questions, trying out new approaches and reflecting critically. Critical alignment, through inquiry, is seen to be at the roots of an overt developmental process in which knowledge grows in practice (Jaworski, 2006).

One of the reasons for introducing inquiry as a tool - for example, in designing inquiry tasks to stimulate inquiry in the classroom - is to challenge the normal (desirable) state and 
question, perhaps, whether it is indeed so desirable. A common approach to teaching and learning mathematics uses text book exercises, such as performing a two-digit multiplication, or finding the length of a side of a triangle using the Pythagorean rule. Such approaches practise skills with the goal that students become fluent with certain operations, students might be seen to gain procedural proficiency. However, we might ask questions about the degree of conceptual or relational understanding that is afforded by this practice (e.g., Skemp, 1976). If the normal desirable state is to be sure that a student can do what is required, and not to worry too much about understanding (a uni-dimensional approach), then it could be that we are denying students an important opportunity - to understand the mathematics they are learning, and to relate particular ideas more widely, both in mathematics and in real world applications; perhaps also to enjoy the stimulation this affords (multidimensional). So, we might ask, what can we do in classrooms to enable students to understand better the mathematics they meet in text book exercises? This is a developmental question. As soon as we strive to address such a question, we enter an inquiry or a research process.

Participants in an inquiry community are not necessarily satisfied with the normal (desirable) state, but approach practice with a questioning attitude, not to change everything overnight, but to start to explore what else is possible; to wonder, to ask questions, and to seek to understand by collaborating with others in the attempt to provide answers to them (Wells, 1999). In this activity, if questioning is systematic and participants set out purposefully to inquire into their own practices, they become researchers. This means that while aligning with normal practice, participants inquire into the nature of practice with a view to improving its outcomes. Critical alignment is therefore at the roots of a developmental process based in inquiry. Collaborative inquiry leading to critical alignment allows questioning of established ways of doing and being and the possibility for new ways of seeing activity in classrooms and the mathematical learning of students.

\subsection{Developmental research in practice}

Developmental research as a methodology is based on ideas articulated by Freudenthal (1991) and Gravemeijer (1994) in the context of curriculum development. The application to teaching development entails interconnected cycles of knowledge creation (a research cycle) and practice development (a developmental cycle) that model a dialectical evolution of both theory and practice. These cycles, have been represented diagrammatically by Goodchild (2008, p. 208) (See Figure 1). The figure represents an ideal of developmental research depicting simultaneous and united processes of research and development, and the synergy 
that exists between these processes. The figure is used to illustrate processes; it is not, at least in this paper, used as an analytic framework. The research cycle, to the right of the diagram represents the concern with the creation of scholarly knowledge and with principled explanations (the focus of Section 4.2). The developmental cycle represents the concern to improve practice and the creation of craft knowledge (focus of Section 3). Both cycles are based upon the articulation, implementation, testing and evaluation of hypotheses, and are concerned with knowledge creation. The cycles exist in unified actions that constitute the developmental research cycle (focus of Section 4.1).

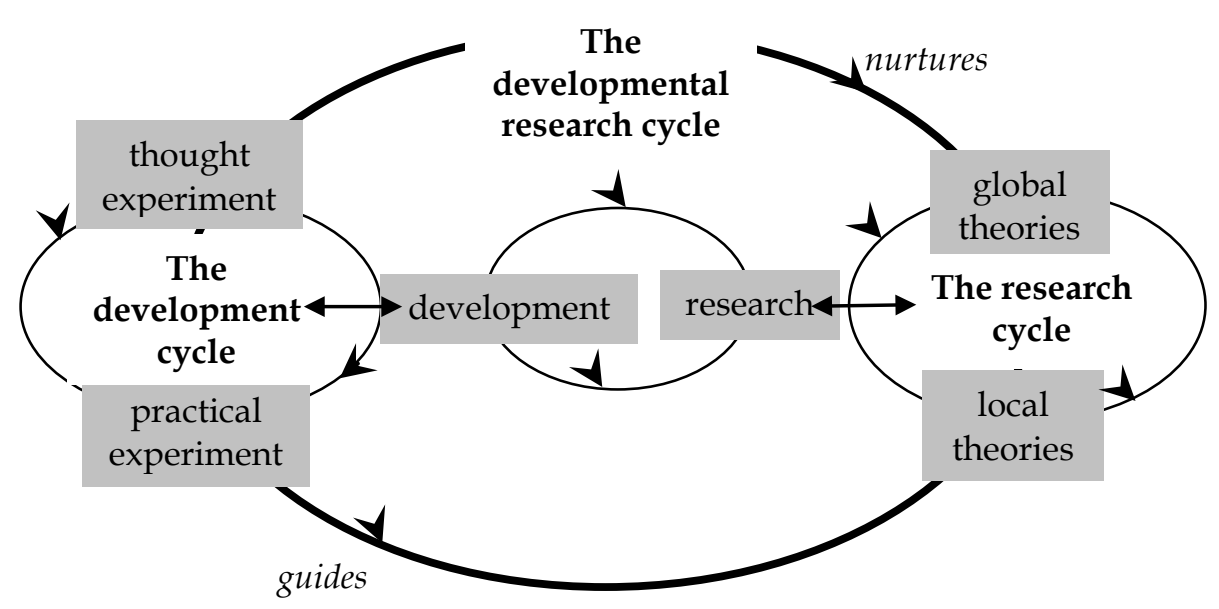

Figure 1: Goodchild's diagram of a developmental research cycle

As the diagram suggests, development and research are continuous and concurrent processes. The arbitrary point chosen to begin a sequential description of these processes is the planning of the project from which this report emerges, that is in the research cycle depicted on the right of the diagram. We set out within a framework of community of practice theory (Section 2.2) which constitutes the global theory. Local theories, especially relevant to mathematics teaching, such as inquiry and insider/outsider research (Section 2.1) are introduced to produce a developmental theory within the chosen global framework. The dialectic between global and local theories spawns the notions of communities of inquiry and critical alignment (Section 2.3). The proposal for the project envisaged three distinct developmental phases, briefly these were: community building, innovation and inquiry, and goal setting. The research cycle is sustained through internal seminars and reporting to the wider, international, mathematics education community. 
Research guides the developmental cycle through planning meetings and feedback from participating teachers. In other words the cycles have reflection and feedback mechanisms embedded to enable continual adjustment of processes and implementation. The development cycle 'begins' with a thought experiment that is based on teachers' and didacticians' experiences, professional discourse and the exercise of imagination. Thus, the regular teaching cycle of practice evolution in which most teachers regularly engage (plan for teaching, act in the classroom, reflect on experience, feedback to regular planning) is transformed into a teaching inquiry (research) cycle by introducing to the teaching cycle: systematic observation, analysis and reporting. The inquiry cycle is thus, plan for teaching, act and observe the action, reflect upon and analyse the experience, feedback to future planning and report to the community.

In the inquiry cycle, systematic observation and analysis inform the reflective process. Reflection and feedback provide possibilities for re-planning in better informed ways leading to a more knowledgeable design of teaching. When observation and analysis are included data are collected relating to action and this is analysed to add evidence to reflection. Such a cyclic model clearly relates to the familiar iterative cycles of action research and design research. Each of these research approaches might be seen as developmental. When participants engage collaboratively both insider and outsider research is involved. Teachers inquire into their own practice, they are developing their own "craft/professional” knowledge within their own practice; they are “insider researchers”. Didacticians observe, collect data/evidence and provide critical material upon which teachers might reflect, but they are not 'insiders' within the classroom in terms of authority or responsibility for teaching, hence didacticians are outsider researchers within the inquiry cycle. Knowledge is generated both to inform practice directly and also to enhance knowledge in teaching more widely. Reflection on the outcomes of successive inquiry cycles informs, and thus nurtures the theoretical model upon which the project is founded by affirming or challenging underlying principles of the model.

Didacticians are then insider researchers within the encompassing developmental research cycle.

\subsection{Implementation and methodology}

The teaching development projects from which we report set out to establish learning communities of inquiry between teachers in school, between teachers across schools, and between teachers and didacticians. Over 30 teachers from eight schools participated, covering the range of education from primary school (Grade 1, children aged 6 years old) through to 
upper secondary (Grade 13, students about 19 years old). Three phases of fieldwork (community building, innovation and inquiry, and goal setting) each took place over one school year during which workshops at the university (16 in three years) and associated developmental work in schools were the main activities. Every workshop started with mathematics: one or more mathematical problems were introduced and worked on by teachers and didacticians together in plenary or small groups. Discussion of mathematics led to didactical and pedagogic discussions, both at specific school levels and in general. Teachers decided on their school activity in relation to the workshop and were free to request didacticians' support in school. It was common practice that teachers gave an oral report at a workshop, presenting and raising issues from their school activity. Three didacticians were associated with each of the eight schools; one of these took direct responsibility for liaising with teachers and organizing support as requested and agreed. Overall, didacticians planned and organized workshops and teachers were the leaders in schools; however, there was reciprocity in both directions through consultation and discussion. Several school teams communicated from the project to other teachers in their school and organized joint activity. In some cases, teachers in different schools collaborated, forming their own small community. (For details see Jaworski et al., 2007.)

In Community of Practice terms (Wenger, 1998) workshops and activity in schools provided a joint enterprise in which all participants had a mutual engagement. Reporting school/classroom-based activity in workshops became part of the overall enterprise of the project. Opportunities for discussion, exchange of ideas and experiences contributed towards the development of a shared repertoire. Imagination was stimulated through plenary presentations and group discussions. Inquiry, the inquiry cycle and critical alignment were made explicit in many activities, for example, in the approach to mathematics, in the design of tasks used in lessons, and in reflection upon teaching and learning (For further details see Jaworski, Goodchild, Eriksen, \& Daland, 2011).

Data collected from all activity at which didacticians were present, including their own meetings at the university, included audio- or video-recordings, field notes, documents (workshop or classroom tasks, students' work etc.) and results from classroom testing of students. It was more difficult to gather data from activity that involved only teachers (and students). It became common practice for teachers to invite didacticians to video-record lessons in which inquiry-based activity would take place. 
In this article we report a case from the project based on a "key event" in its historical and social context. The key event in this case is a completed inquiry cycle undertaken by upper secondary teachers within the first year of the project. It is chosen primarily because of its significance in being the first completed cycle within the project and thus an important opportunity for learning. Although the event takes place within the long-term development of those involved, it is bounded here by the initial proposal to work on a specific topic through to teachers' reflections on the implementation and developmental process. The analysis considers the corpus of data relevant to understanding the key event which may be subdivided into key episodes. Reporting such an event challenges the researcher to demonstrate trustworthiness, as suggested by Freudenthal (1991):

...developmental research means: experiencing the cyclic process of development and research so consciously, and reporting on it so candidly that it justifies itself, and that this experience can be transmitted to others to become like their own experience. (p. 161)

We focus on a case of the engagement of teachers in one upper secondary school and the activity that contributed to the observed events and emerging issues. It is possible to include many factors in our account: however, our aim of analysis here is to expose critical alignment and inquiry. We employ a narrative style drawing on analyses conducted shortly after data collection, and then offer a post hoc interpretation relating to methodological and theoretical synergy. Significantly, the early encounter between differing expectations of teachers and didacticians brings to the surface issues in participants' alignment, the development of a community of inquiry, and engaging with inquiry in the teaching and learning of mathematics. Our purpose is to show the developmental process in a retrospective account, drawing on the knowledge we have now, while presenting analysis of data that took place early in the LCM project.

\section{A case study: An introduction to linear functions}

The data upon which this paper is based comprises about twenty hours of video and audio recordings together with field notes and documentary material such as text books and teaching material. Each sub-section below relates to a specific phase within the inquiry/development cycle. Data is examined from a phenomenological perspective in which the intended outcome is an analytic account that exposes the teachers' perceptions and understandings of their engagement in the development cycle. In section 3.1 we outline the analytic approach taken to produce the narrative account; subsequent sections provide only the narrative account that emerged from the analysis. We emphasise that our unit of analysis is the event. We could undertake smaller grained analyses of segments of activity or of dialogue which could be 
highly informative on aspects of teacher thinking or of classroom practice. However, our chief aim here is to capture elements of the developmental process and the synergy between theory and development.

\subsection{Process of interpretative analysis drawing on various data sources}

The case consists of the inception, preparation and teaching of three lessons at Dronningens Upper Secondary School by a team of three teachers (Osvald, Kristin and Mari) and subsequent stages of reflection. Three didacticians (from the team of 12) were principally involved: Eli, the Project Director, Leo the liaison member for this school, and Liv. In Norway students in upper secondary school (Grades 11-13) are typically aged 16-19 years. Teachers at this level are usually well-qualified, generally to masters' level in their specialist subject (here mathematics). In the following, translations from the original Norwegian are marked (T) otherwise the original English is used; hesitations and undue repetition have been removed to improve readability. All names (teachers, didacticians and school) are pseudonyms. The events that contribute to this case occurred over the course of one year at the beginning of the project. The analysis draws on data generated from the point at which didacticians visit the school to negotiate participation in the project. The final event included in the case was a meeting of didacticians and teachers at the end of the first year in which teachers were invited to reflect on their experiences in the project.

\section{Interpretative analysis of data}

We outline in this section our analytical process in reaching the narrative accounts that we present in this article. In all cases, we start from data that relates to the insights we present. We make interpretations based on this and other data and present an account that aims to make sense in general and specific terms. We begin by referring to data generated from the first workshop in which we analyse teacher Osvald's words. He reported back, in a plenary session, on the discussion he had with colleagues in a small group at the workshop concerning a lesson that he and his colleagues hoped to design.

Osvald: [In the small group] we talked about when we shall start up ... so we thought we would plan a topic, a starting point, a topic that we will present to the pupils. And in contrast to picking out an interesting topic that we shall teach, we picked out something we thought was boring (laughter). So we thought we should make a lesson which would make it more exciting and we thought of something for the lowest grade [three classes at grade 11] in school and we have linear functions and straight lines that we think was a boring topic to present. We shall open with this. (T)

Here Osvald is reporting back from the small group discussions that he and his own school colleagues have had earlier in the workshop. He is aligned with the practice: he chooses a topic within the syllabus, which his students (pupils) are expected to learn (and other data 
reveals that he follows the textbook, he is concerned that students will not be disadvantaged in their examinations). He is also aware that something might be improved and the issue upon which he and his colleagues choose to focus is a topic that is less interesting to teach and learn.

Issues that we suggest to be considered here (square brackets indicate an increased level of interpretation) are:

- Focus on the syllabus: what must be taught. [established practice]

- Challenge: take a topic that is not interesting (to present); create a lesson that makes the introduction more exciting. [Possibly a move towards more inquiry-based teaching (a concept introduced in the project description and emphasized in the first workshop)].

- Take a mathematical topic for students in grade 11 and consider how students' experience might be modified. [Engagement in the project - to develop an alternative teaching approach where possibly they see the existing one to be deficient.]

- Primary focus is on the development of students' affective rather than cognitive experiences (should not be "boring”). [Possibly it is believed that this will lead to better cognitive engagement, although this is not articulated.]

\section{An interpretation of what is said, relating to other data sources}

Concern with the curriculum is consistent with utterances by Osvald at other times, for example at an earlier point in the workshop, commenting on three investigative mathematical tasks that had been used in small group activity he observed:

We have a text book ... they're nice problems, but take quite a lot of time. That's the problem if you have a strict syllabus $(\mathrm{T})$

two (of the three tasks presented) were more amusing ... (the third task is) the most applicable $\ldots$ set in the context of the syllabus (T)

Teachers are expected to align with the curriculum. By taking eleventh grade classes they choose to try things out with the classes that are furthest from the high stakes examination; this is further evidence of aligning with the structures and organization of school. The teachers' starting point here is to introduce inquiry approaches by developing or adapting something from routine practice.

When choosing a topic to develop, the teachers decided to focus on something that they wanted to be more exciting. The contrast between amusing (and exciting) tasks and curriculum tasks fits with Osvald's earlier comment about the three investigative 
mathematical tasks presented earlier in the workshop. We also note that teachers share didacticians' concern for students' enjoyment, in addition to understanding and proficiency (See section 1).

About two months after the first workshop reported above, two didacticians (Eli and Leo) visited Dronningens school to meet with the teachers and school principal to discuss the school team's engagement in the project. The teachers re-emphasised their wish to work on the teaching of linear functions. Didacticians were pleased to get involved, so the meeting consisted largely of a mathematical discussion, referring to textbooks, areas of difficulty for students, and ways in which the topic might be taught. The meeting closed with a request by the teachers to come to the university to meet with didacticians for further informal planning away from the pressures of school.

\subsection{An inquiry cycle in teaching linear functions - planning}

This section is a narrative account based on analysis of the requested informal planning meeting, conducted in the style exampled in section 3.1 above. The meeting (involving teachers Mari and Kristin and didacticians Leo and Liv) lasted about three hours and the discussion spiralled, visiting and revisiting issues, with an embryonic lesson plan gradually emerging (such as Engeström, 1994 describes when reporting on teachers' collaborative planning). Suggestions from didacticians, described below, opened up possibilities with which teachers were eager to engage. In Wenger's (1998) terms, it seemed that one didactician's experiential account, and a published idea, stimulated the teachers' imagination so that they proceeded by "extrapolating from (their) own experience” (p. 173). We see this as the beginnings of teacher inquiry into their own practice.

\section{Issues experienced as challenging by teachers}

A challenge acknowledged by the teachers was that the first year syllabus at the upper secondary school recapitulates work that students have experienced earlier. In their classes they have students who have not been successful in their prior experience with a topic and others who have attained intended learning outcomes of the lower secondary school syllabus. The result is that the first year syllabus is boring, all students have met it before and some are left unchallenged. Teachers wondered if open ended, inquiry tasks might hold the key to give all students a fresh and challenging experience of the topic and mathematics. In this meeting the teachers also sought approaches that would address the problems of learning mathematics which their students experience. They reported that students do not appear to make links between related topics, and find it difficult to take knowledge from one task within a topic to 
another. It seems that the students do not form the desired (-by-the-teacher) understanding of the mathematics they are studying, and one of the teachers said that she would like some tips on tasks that would help students understand better. However, the teachers were also seeking approaches to introduce a topic that would provide a foundation, not just for the one topic but for other related topics. Thus they sought an introduction to linear functions and straight lines that would support their further experience in functions, solving equations graphically, regression lines of best fit, etc. They also wanted to enable students to understand different forms of representation (equation, table, graph) so that they could "move" fluently between them.

\section{Issues constraining teachers' practice}

The textbook used by the teachers appears to lead the sequencing of topics, and provides a source of tasks for students to do, but it does not, in itself, appear to form an obstacle for development. The obstacles for development appear to be the same obstacles that teachers recognise as problems in their current approaches; for example students’ behaviour (restlessness amongst the students leads the teacher to conduct much of the lesson from the front of the room) and lack of space within the classroom (which prevents experimenting with alternative forms of organization and grouping). Thus teachers argued that prolonged "inquiry tasks" are not a feasible option, tasks need to be fairly well contained with clear short term goals; however, this does not mean that students cannot be gradually prepared for tasks of longer duration. The curriculum hangs as a cloud over all thoughts of development because students must be prepared for their tests and the teachers believe that this requires them to spend a substantial amount of time using their established approaches and the tasks found in text books that are similar to the tasks found in tests. Kristin summarised their frustration,

But what irritates me also is that the whole time I see the limitations and not the possibilities. (T)

which might be interpreted as critical alignment to her regular practice, but it seems that she does not recognize her agency or allow her imagination to work on the constraints that she experiences. She suggested that, perhaps, working with didacticians can help overcome limitations and help possibilities emerge.

\section{An alternative (inquiry) approach - an idea suggested by didacticians}

After these issues had been aired and discussed, the didacticians offered a suggestion which initiated the planning phase of an inquiry cycle. Leo introduced a lesson idea, a "starting point” from a teaching resource published by a British mathematics teachers' professional association (Ollerton, 2002) and Liv recounted her experience of using the same idea with 
teacher education students. The lesson idea commences by asking everyone in the class to write down a pair of whole numbers that satisfy the equation $x+y=7$. The published resource continues with a list of supplementary questions and extension tasks that focus attention towards graphing linear equations (and extended to hyperbolic equations “ $x y=c$ ”). The teachers were attracted by the suggestion: Mari remarked, “I am very keen to try this” (T); Kristin agreed, "perhaps just start with the first equation” (T). In discussion about the task, they considered the particular characteristics of their students; for example, that students are not accustomed to extending tasks on their own initiative and that their classes include a wide range of competencies. Kristin and Mari agreed that the more open the task is at the start the more adaptable it will be for students at different levels. Further they must be ready with hints and suggestions (on "the back of their hand") that will enable students to progress with the tasks, without giving unnecessary cues, for example they discussed how to suggest that students represent the number pairs in a diagram without directly suggesting a Cartesian graph. They were also concerned about how the task would be managed: thus some hints and suggestions should be presented on paper that could be quickly distributed to groups without much delay.

\section{Development of an inquiry based lesson - teachers adapt the idea}

The discussion in the planning meeting laid the foundation for the final product that emerged from subsequent meetings of the teachers that took place before and during the Christmas holiday. They produced a series of four "cards” (reproduced in Appendix 1) that structured the activity into a number of sub-tasks. The cards correspond closely to the suggestions made by Ollerton (2002), as illustrated in Table 1. However, Ollerton's suggestions are not followed uncritically: the discussion in the meeting exposed the teachers' rationale for adaptations and additions in order to meet their educational and pedagogical ideals. For example, they remarked that it is better to ask, "what if one of the numbers is nine?" (following Ollerton’s suggestion) than to ask “what about negative numbers?” The activity was split into four separate work cards that could be handed to groups as appropriate and the questions or tasks were laid out to be as open as possible and avoid unnecessary guidance. There is a clear mapping between Ollerton's suggestion, the planning discussion and all of the “cards” produced. Table 1 is an abbreviation of this mapping, and illustrates how the planning discussion mediated between the published material and the first card produced by the teachers. 
Table 1. Mapping between Ollerton’s "Starting Point”, the planning discussion and "Card 1".

\begin{tabular}{|c|c|c|}
\hline Ollerton 2002, p. 1 & Planning comments & Card 1 \\
\hline $\begin{array}{l}\mathrm{x}+\mathrm{y}=7 \\
\text { Starting point } \\
\text { Ask everyone to write } \\
\text { down two whole } \\
\text { numbers that add up to } \\
7 .\end{array}$ & $\begin{array}{l}\text { Mari: If you give them that }(\mathrm{x}+\mathrm{y}=7) \text { one } \\
\text { can find two numbers each, in the group } \\
\text { can find two, and so ... they will have } \\
\text { different (pairs) when they put them } \\
\text { together (T) }\end{array}$ & $\begin{array}{l}\mathrm{x}+\mathrm{y}=7 \\
\text { 1. Each student write down } \\
\text { two whole numbers which } \\
\text { add up to } 7 .\end{array}$ \\
\hline \multirow{2}{*}{$\begin{array}{l}\text { What and how many } \\
\text { different answers are } \\
\text { there? }\end{array}$} & \multirow[t]{2}{*}{$\begin{array}{l}\text { Mari: Which group can find the most } \\
\text { [number pairs]? (T) }\end{array}$} & $\begin{array}{l}\text { 2. Can you find more such } \\
\text { number pairs? }\end{array}$ \\
\hline & & $\begin{array}{l}\text { 3. How many such number } \\
\text { pairs can you find? }\end{array}$ \\
\hline $\begin{array}{l}\text { Turn the numbers into } \\
\text { ordered pairs and } \\
\text { graph them }\end{array}$ & $\begin{array}{l}\text { Mari: There will be a [reward] for those } \\
\text { who find the most points here! } \\
\text { Not points! Most numbers (T) } \\
\text { Liv: One must not imply that we shall } \\
\text { have a straight line (T) } \\
\text { Kristin: Say it in a way that does not say } \\
\text { anything about the thing that will be } \\
\text { drawn. Hoping that some will possibly } \\
\text { try to draw. (T) }\end{array}$ & $\begin{array}{l}\text { 4. Draw these number pairs } \\
\text { on millimeter paper }\end{array}$ \\
\hline
\end{tabular}

\subsection{An inquiry cycle - Implementation in the classroom}

Teachers and a didactician (Leo) met the day before the planned lessons were to take place to discuss the implementation of the lessons and use of the work cards as well as arrangements for filming and organizing the classroom. The teachers had previously told their students about the lesson and the visit by didacticians and had set up working groups and group leaders who would come in advance to arrange furniture. Each of the three teachers would use the cards with their class. The three lessons would occur in sequence, so didacticans could be present and video record all three lessons, each of 1.5 hours duration. The teachers wanted students to use the cards with as little introduction as possible; they explained that they wanted the students to decide what was to be done through discussion with other students in their groups, rather than relying on teacher direction. The main concern in this final planning meeting was to consider practical issues of managing the cards, the filming and ensuring there were additional tasks at hand in case students finished quickly. Leo asked if the teachers had considered the time students might need to draw the number pairs (Card 1, question 4). The teachers had thought about this, they felt that some students might be a little slow (in drawing) and had thought that the task might be completed by just part of the group, whilst others discussed the tasks.

The classroom implementation of the cards resulted in nine hours of video recordings - two cameras were used in each class, one static focused on a group of students, the other 
"roaming” to include teacher-student interactions. In accord with our unit of analysis, we focus here on the teachers' engagement in the project, rather than on the students' activity. Due to limitations of space, we confine the narrative of the implementation to one episode from one group in Osvald's class, significant because its substance recurred in all classes.

The fourth task on card one, Draw these number pairs on millimetre paper [i.e. graph paper], created problems for Osvald's students; they did not understand what was required and asked each other what it meant "to draw" number pairs. At first, Osvald did not intervene, thus giving some space for the students to resolve the problem for themselves. Then after some minutes, he offered a suggestion which enabled the students to realise that a graphical representation was required: he said: "Look at that expression x plus y is equal to seven." (T) One student answered "Yes” and another: ”is it wrong?” (T) The students requested a new sheet of graph paper for drawing, but still did not appear to think of using the coordinate system. Osvald then gave a further suggestion: as he said later, “..., a new key word. I gave a key word, I gave $\mathrm{x}$ and $\mathrm{y}$ to another group.” (T)

We draw attention to three significantly related issues here:

- Teachers' struggle in the planning meeting to be satisfied with the wording of the task to “draw number pairs”.

- Teachers' desire not to give the game away by telling too much

- The students' difficulties in interpreting the instruction to "draw" number pairs and teachers' corresponding difficulty in deciding how to respond.

\subsection{An inquiry cycle - Review of the classroom activity}

A review meeting between didacticians Eli and Leo and the three teachers took place in an evening, about two weeks after the lessons, at Eli's home. It was hoped the location would be more conducive to informal discussion than in a school or university environment. Leo and Liv had selected short video episodes from each of the lessons and these were viewed and discussed. In the analysis we are interested in

- teachers' reflections on the value of the tasks in generating students' attention to concepts in linear functions,

- teachers' recognition of aspects of their own learning, and

- new ways of doing and/or seeing matters that seemed to emerge from the overall experience of designing and using the tasks. 
The word "inquiry" was not used at all during the meeting. However, the nature of the tasks, the engagement of teachers in the design and use of new tasks, and the joint reflection on events, all speak to the inquiry nature of the activity engaged. We (authors) see inquiry here in the students' mathematical activity with the tasks, in teachers' exploration into teaching and in our combined reflections into what occurred, how we thought about it and what we (teachers and didacticians) learned.

Early in the viewing, teachers commented on the activity (and learning) of the students. Students seemed not to understand what the task was actually asking them to do: perhaps it was a more open task than they had experienced before; perhaps they were used to having more direct instruction. For example:

"[Students] are not used to work in this way and they get frustrated ..."

"Many students are not curious enough - they don't see the point [of the task]"

It was as if the teachers needed to apologise for their students who seemed not to be doing what the teachers hoped (or what teachers thought the didacticians hoped).

One of the episodes chosen showed the students in Osvald's class struggling with the instruction to draw number pairs. Students did not know what to do with this instruction. Osvald said he thought that asking them to draw would take them immediately to drawing a graph, so he was surprised that despite much discussion, they were unable to see what to do. It was Osvald's comment to another group, mentioning $\mathrm{x}$ and $\mathrm{y}$ [axes], that led to students' recognition that they could draw a graph. Eli asked in what way the original question (in Card 1) might have been changed to make this less of a stumbling block. They discussed alternative words like “mark” or "plot”.

Teachers suggested that they had learned something from this episode. They saw what their students did (or did not do) which contrasted with their expectations and led them to realize that, however obvious it might seem to the teacher, students can see things differently. On the other hand, they were pleased when students responded to a question, about how many points there would be, with the words "infinity to the power infinity" (T). They thought this indicated a degree of understanding.

Osvald clearly thought that the investigative process was over-lengthy; he would want to shorten it another time. However, he acknowledged that it had possibly led to students being better prepared for what came next -- there had been "food for the next lesson" and most people had benefitted. 
... because of this session, ... I got the feeling that, in the next lesson, when I should summarise it and go further in more detail, talking about the slope and the intersection with the $y$ line, I got the feeling that it helped to have been through the session before [the recorded lesson]. After the lesson I said to myself, maybe it was not so in vain because they have learned something, and what they have learned made it easier to understand what I'm saying now - perhaps; I'm not sure.

These tentative words (“I got the feeling ...”; “... perhaps, I'm not sure”) seem an honest reflection from Osvald that, despite his perceptions of time being wasted, perhaps it had "not been in vain” after all. Perhaps there was some overall value. When Leo asked what the teachers might do differently another time, Osvald replied "I would like to do something, but not so long. Make a sheet with a task and see how far they get. It's important that they do something and try something. But I would summarise earlier”. Kristin said that on the whole the experience had been successful and that she would try something similar next year. She suggested modifying the introduction to text book sections so that students know that when they start something new they are expected to do some kind of exploratory work. This seemed like a very positive suggestion in relation to the remark from Kristin, quoted above, about seeing limitations.

We emphasise that this was early in the project (first 6 months), so that ideas of inquiry and connotations of designing inquiry tasks and behaving in inquiry ways were very new to the teachers. No language had yet developed to articulate what was experienced. However, we see teachers as both critical of the experience from the point of view of what they saw to be achieved and the time and effort it had involved, but also, just starting to recognize positive elements from the perspective of students' involvement and understanding and ways in which they, the teachers, might continue the inquiry-based activity. We recognize the slow speed of development - slow for the students in recognizing what was expected of them in these new kinds of tasks, and slow for the teachers in becoming aware of the complexity of what they were trying to achieve and its relation to their established ways of working. In retrospect, it was slow also for the didacticians who had to recognize the slow nature of the developmental process and their own associated learning about teachers' perceptions, established ways of being, and the constitutional (i.e. curriculum, exams etc.) and institutional constraints of their practice.

\subsection{An inquiry cycle -- feedback to the project community}

Six weeks later, now two months after the implementation of the lessons, two of the teachers (Kristin and Osvald) presented their work at a project workshop. In a plenary session they talked about the background and planning of the cards and lessons and they included the 
video episode of students in Osvald's lesson seen in the review meeting. They reflected on their experiences and feelings about the whole teaching process and their students' engagement. Their account followed the sequence of events summarized above; thus providing a useful means of verification of our interpretation. Kristin repeated that the rationale for choosing the topic was because, "we thought, possibly, it was a bit boring and so alright to try something” (T). They confirm our account, based on the data record, of both the origin and developmental process that resulted in the four "cards". However, in their reflection they do not indicate whether the new approach had made the topic more enjoyable. Kristin and Osvald's presentation included some description of the students shown in the video presentation and how the classes had engaged and responded to each of the questions posed on the cards. They reflected on modifications they would make, in the light of experience, for example, after the students had drawn the line $\mathrm{x}+\mathrm{y}=7$, the next task required $\mathrm{x}+\mathrm{y}=12$. Many students had drawn the axes so that " 12 " lay outside the page, and Kristin observed that it would have been better to use a constant less than seven. Noticeable in the presentation is the frequency with which Osvald and Kristin refer to "time":

Kristin: "The topic fitted well in relation to the schedule.” (T)

Kristin: It (preparation) went over a fairly long period; that was very good because then we were able to reflect more over which problems we could encounter. (T)

Osvald: (On students' difficulty with the notion to draw a number pair) So a lot of time was wasted just to do what was required. (T)

Kristin: I think it took quite a long time before they (students) saw that the points extended beyond the first quadrant. (T)

Osvald: It was an hour and a half we used, well ... just under two lessons ... I found that I must use a little time for summary. ( $\mathrm{T}$ )

Osvald: We used two lessons here, we used even more, much more time for preparation ... and we cannot use so much time for every topic. However, in summary, it is my opinion that it is [a good use of time] in respect of going through content for students. I felt I had gained from what had been done in the two lessons as we went further ... finding solution sets of equations, ... linear functions, intersection points, etc. ... there is great transfer value ... where earlier I had used a lot of time, making tables, ... plotting points, ... draw the line ... I felt it went much quicker. ... I felt that I had not lost much time. (T)

The teachers emphasise that the new approach was very demanding on them in terms of preparation time, and that this may have a significant influence on the extent they align themselves to the project. Here they reflect on both their time capital and the investment in didactical time that had a later payoff (Assude, 2005) in addition to their own personal time given to the preparation. 
These repeated references to time take on even greater significance when set within the context of the data used in developing this case. At the very outset of the project the group of teachers at Dronningen's school had expressed themselves as only prepared to commit to the first year, in case they found the project placed too much demand on their time. Osvald's concern with teaching time and the syllabus that they had to cover was also evident in his statements in the first workshop. It appears then that the teachers are most conscious of the pressure of time in their practice; on the basis of their utterances it appears that they are more conscious of time and curriculum than of their students' experiences of mathematics. Nevertheless, they had been willing to engage in a lengthy period of preparation to develop a lesson on a topic that was experienced as "boring". They mentioned that the idea might be modified so that future implementations are not so time demanding; for example, that it was necessary to ensure students could “do" what was required, such as drawing number pairs. However, time was later saved as new topics were addressed.

\section{Discussion}

In this section we review first the reported case in the context of the embracing developmental cycle (Figure 1), and then the consequence that this might have in terms of the theoretical underpinning depicted in the research cycle. The case study reveals that critical alignment and inquiry bring uncertainty and risk, and foster tensions within the teachers’ practice and between the practices of teachers and didacticians. The case also brings fresh understanding that will facilitate further the methodological synergy between theory and developmental action.

\subsection{Teachers' engagement and contribution}

Our story, as authors, suggests the following. The teachers committed themselves initially to work within the project for one year. They chose a topic in their syllabus to work on -- linear functions, because it comes at the beginning of the course, far from the high stakes examination and they perceive it as "boring" -- in other words where they would do little damage and maybe do some good. They entered into the design and planning with commitment to the project, one could argue that they did what was necessary to be a part of the project as they perceived it, thus fitting Wenger's explanation of alignment. Throughout the process it appears that a major concern of the teachers is with time demands, and they measure their "contribution" to the project in terms of what it has cost in terms of time rather than what it has rewarded in terms of students' improved learning experiences. Perhaps it is much easier for the teachers to measure things against the clock than to assess whether their 
students have learned more, better or differently. They have "given” time, they have taken risks, they have provided opportunities for the project's activities. We suggest that the teachers see lesson time as a form of balance sheet - more time here (for the project) saved time later. But they have also given a lot of their own time (for preparation) and they do not (yet) see the possibility of longer term rewards. Our interpretive account here seems consistent with a statement made by the upper secondary teachers in the following June when they say “we feel that we have done a lot for you but not received much in return” (Bjuland \& Jaworski, 2009).

However, the teachers have contributed to the project's development much more than the time they have given to the preparation of their lessons. The wider context of the project is important here as we reflect on what we have gained and learned as didacticians. This school team was the first to engage overtly in teaching innovation: the filming in their classrooms was the first in the project and was influential in encouraging other school teams to follow suit. We felt the example of the Dronningens' teachers enabled other teachers to overcome initial reservations about filming, and indeed it became fashionable to be filmed, thus video recording entered into the project repertoire. As the language of inquiry developed in the project (Bjuland \& Jaworski, 2009), inquiry became associated with trying out new ideas and gathering data on which to reflect. Several teachers, or groups of teachers worked with didacticians explicitly to explore areas of mutual interest (Bjuland, Cestari, \& Borgersen, 2008; Jørgensen \& Goodchild, 2007).

As we noted at the end of Section 1, we wanted to work with teachers to reflect on current practices and to consider possibilities for change. This certainly happened in the events we have reported. The case shows one interpretation of the developmental methodology explained in Section 2. The cycles of activity in practice, between didacticians and teachers, illustrate the developmental cycles and these feed into the development of theoretical ideas evolving in the research cycle. Inquiry is a crucial category of action within the project and thus an analytic category, although, since the case reported comes from early days in the project, the planned community building phase, and the language of inquiry was not yet being used by teachers. However, the teachers' actions were consistent with an inquiry cycle and provided substance for the articulation of inquiry that became the focus of the second phase (year) of the project activity. 


\subsection{Developmental research: critical alignment and synergy}

We refer to the link between desirable outcomes in school practice and inquiry in teaching. The teachers could see value in making teaching of linear functions less boring. The identification of a topic as boring; seeing that something could be done, is a sign of critical alignment -- a state in teachers' school practice (established community) that was less than “desirable” (Brown \& McIntyre, 1993). It focused creative energy on development. Didacticians saw teachers' engagement in designing the new approach as “inquiry in teaching”; exploring established ways of doing and being and learning about new possibilities and their outcomes - making a start towards an inquiry "way of being”. It was important that the inquiry activity originated with the teachers and was not a task pre-designed by didacticians for teachers to undertake. However, inquiry is slow to develop; this we certainly learned. The developing project produced many cases through which we can inspect our theories of inquiry, inquiry community and critical alignment. Through such inspection, our theoretical knowledge developed. By this we mean that our knowing of inquiry became grounded in our knowing in practice, through the developmental research approach.

Critical alignment entails uncertainty and risk; this is illustrated by a reluctance to "tell”. For example, the teachers wanted students to see for themselves how drawing number pairs is valuable for seeing the infinity of solutions to a linear equation in two variables. They debated how to enable students to come to this recognition without being told directly, and in the end they perceived that hints were needed, or more clearly worded or focused questions. This aspect of the lesson did not work out as well as they had hoped, but they learned from it. On the other hand, the activity led to pleasing outcomes from the students, such as the revealing words "infinity to the power infinity". Teachers could not have prompted this directly. Similarly for the didacticans: they did not wish to give teachers pre-designed tasks, to tell the teachers what to do in their classrooms. In the Dronningens case, encouraging teachers' own choice of topic and supporting their design of tasks resulted in activity on the part of the teachers that could not have been pre-designed. The teachers owned this activity in ways that could not have been possible if they were undertaking a task set by didacticians. Nevertheless the input of the didacticians was also important. Ollerton’s (2002) tasks and Liv's account of her use of them was clearly significant for the teachers. They fitted well with what the teachers had in mind themselves. This seems an important synergy. The uncertainty of outcome was often an uncomfortable position to endure - taking more positive action could have relieved some of the tension but with ultimate sacrifice of ownership. The 
theory of “critical alignment” became more clearly conceptualised during this time as it was reinforced through practical experience.

Critical alignment fosters tensions in practice and between practices. Importantly, there are tensions between alignment in the established community and a critical approach to changing established practices. There are gains and losses in what is achieved. We see the tensions both "pulling-away" and "pulling-back". The teachers' investment of time in the design of the new tasks and their use of tasks in their lessons pulled away from the established "boring" approaches with which they were dissatisfied. However, the time taken was disruptive of other expectations in their professional and personal lives: this pulled them back. The project supported the forward momentum: despite the initial hesitation in their commitment, two teachers stayed with the project for the full three years and continued to play a decisive role (one, Mari, changed her job). Didacticians had to take the tensions seriously and they needed to support the teachers in what teachers found valuable and possible, while promoting inquiry ways of being in practice as and where possible. The nature of this balance developed over time and constituted an important learning experience.

Development of teaching is a slow evolutionary process (Jaworski, 1998) as teachers and didacticians gain awareness of the uncertainty, risks and tensions entailed by critical alignment. Teachers realized that the exploratory approach was hugely demanding on their time, both in taking time for planning and in valuable classroom time. Established demands of curriculum, school practice and personal life suggested it to be unrealistic to take such an amount of time. There was clear rationalization in the teachers' articulated reflections and reports. Didacticians had much to learn about relationships between idealized new practices and the demands of established communities. Regular meetings of didacticians in the university addressed outcomes from cases such as Dronningens and didacticians realigned themselves to the new knowledge that was developing through the practices of the project. These reflections on our activity and our learning from it illustrate the synergy we spoke of earlier. We do not claim, at the stage of the project reported, for either the Dronningens teachers or the didacticians working with them, that we had established a community of inquiry with effect in schools in any absolute sense. However, we had all engaged in inquiry processes with critical alignment to established ways of being and doing and concomitant learning. What we have presented above, we hope, is clear evidence of this learning. We choose to close our account at this point, without a "conclusion” because nothing is concluded. Our report has reached a point in time in the continuing evolution of the project 
and the teachers' co-learning partnership with didacticians, the cyclical processes of development and research continued.

\section{References}

Assude, T. (2005). The management in the work economy of a class. a case study: Intergration of Cabri in årimary school mathematics teaching. Educational Studies in Mathematics, 59, 183-203.

Bjuland, R., Cestari, M. L., \& Borgesen, H. E. (2008). The interplay between gesture and discourse as mediating devices in collaborative mathematical reasoning: A multimodal approach. Mathematical Thinking and Learning, 10(3), 271-292.

Bjuland, R., \& Jaworski, B. (2009). Teachers' perspectives on collaboration with didacticians to create an inquiry community. Research in Mathematics Education, 111(1), 21-38.

Brown, S., \& McIntyre, D. (1993). Making sense of teaching. Buckingham, UK: Open University Press.

Cochran Smith, M., \& Lytle, S. L. (1999) Relationships of knowledge and practice: Teacher learning in communities. Review of Research in Education, 24, 249-305.

Engeström, Y. (1994). Teachers as collaborative thinkers: Activity-theoretical study of an innovative teacher team. In I. Carlgren, G. Handal, \& S. Vaage (Eds.), Teachers' minds and actions: Research on teachers' thinking and practice (pp. 43-61). London: Falmer.

Even, R. (2008). Facing the challenge of educating educators to work with practising mathematics teachers. In B. Jaworski \& T. Wood (Eds.), The Mathematics teacher educator as a developing professional. Volume 4 of the International Handbook of Mathematics Teacher Education (pp. 57-74). Rotterdam, The Netherlands: Sense Publishers.

Freudenthal, H. (1991). Revisiting mathematics education: China lectures. Hingham, MA: Kluwer Academic Publishers.

Goodchild, S. (2008). A quest for 'good' research. In B. Jaworski \& T. Wood (Eds.), International handbook of mathematics teacher education: Vol. 4. The Mathematics Teacher Educator as a Developing Professional (pp. 201-220). Rotterdam, The Netherlands: Sense Publishers.

Gravemeijer, K. (1994). Educational development and developmental research in mathematics education. Journal for Research in Mathematics Education, 25, 443-471.

Jaworski, B. (1998). Mathematics teacher research: Process, practice and the development of teaching. Journal of Mathematics Teacher Education, 1, 3-31.

Jaworski, B. (2003). Research practice into/influencing mathematics teaching and learning development: Towards a theoretical framework based on co-learning partnerships. Educational Studies in Mathematics, 54(2-3), 249-282.

Jaworski, B. (2004). Insiders and outsiders in mathematics teaching development: The design and study of classroom activity. In O. Macnamara \& R. Barwell (Eds.), Research in mathematics education: Papers of the British Society for Research into Learning Mathematics (Vol. 6, pp. 3-22). London: BSRLM. 
Jaworski, B. (2006). Developmental research in mathematics teaching and learning: Developing learning communities based on inquiry and design. In P. Liljedahl (Ed.), Proceedings of the 2006 annual meeting of the Canadian Mathematics Education Study Group (pp. 3 - 16). Calgary, Canada: University of Calgary.

Jaworski, B. (2011). Mathematics teacher education in a global context. In N.Bednarz, D.Fiorentini, \& R. Huang (Eds.), The professional development of mathematics teachers: Experiences and approaches developed in different countries (pp. 2 - 50). Ottawa, Canada: University of Ottawa Press.

Jaworski, B., Fuglestad, A. B., Bjuland, R., Breiteig, T., Goodchild, S., \& Grevholm, B. (2007). Lcringsfellesskap i matematikk - Learning communities in mathematics. Bergen, Norway: Caspar Forlag AS.

Jaworski, B, Goodchild, S., Eriksen, S., \& Daland, E. (2011). Mediating mathematics teaching development and pupils’ mathematical learning: The life cycle of a task. In O. Zaslavsky \& P. Sullivan (Eds.), Constructing knowledge for teaching secondary mathematics: Tasks to enhance prospective and practicing teacher learning (pp. 143160). London: Springer.

Jørgensen, K. O., \& Goodchild, S. (2007). Å utvikle barns forståelse av matematikk. [To develop children's understanding of mathematics.] Tangenten, 18, 35-40, 49.

Llinares, S., \& Krainer, K. (2006). Mathematics (student) teachers and teacher educators as learners. In A. Gutiérrez \& P. Boero (Eds.), Handbook of research on the psychology of mathematics education: Past present and future (pp. 429-460). Rotterdam, The Netherlands: Sense Publishers.

Ollerton, M. (2002). Learning and teaching mathematics without a textbook. Derby, UK: Association of Teachers of Mathematics.

Schön, D. A. (1987). Educating the reflective practitioner. San Franscisco, CA: Jossey-Bass.

Skemp, R. (1976). Relational understanding and instrumental understanding. Mathematics Teaching, 77, 20 - 26.

Wagner, J. (1997). The unavoidable intervention of educational research: A framework for reconsidering researcher-practitioner cooperation. Educational Researcher, 26, 13-22.

Wells, G. (1999). Dialogic inquiry: Towards a sociocultural practice and theory of education. Cambridge, UK: Cambridge University Press.

Wenger, E. (1998). Communities of practice. Cambridge, UK: Cambridge University Press.

Zack, V., Mousley, J., \& Breen, C. (Eds.). (1997). Developing practice: Teachers’ inquiry and educational change. Geelong, Australia: Centre for Studies in Mathematics, Science and Environmental Education, Deakin University. 


\section{Appendix}

\begin{tabular}{|c|c|c|}
\hline \multicolumn{2}{|c|}{ Card 1} & Card 2 \\
\hline & $X+Y=7$ & $X+Y=7$ \\
\hline 4. & $\begin{array}{l}\text { Each pupil write down two whole } \\
\text { numbers which add up to } 7 . \\
\text { Can you find more such number } \\
\text { pairs? } \\
\text { How many such number pairs } \\
\text { can you find? } \\
\text { Draw these number pairs on } \\
\text { millimeter paper. }\end{array}$ & $\begin{array}{l}\text { 1. What happens if } x=21 / 2 \text { ? } \\
\text { 2. What if } y=4,7 \text { ? } \\
\text { 3. How many different number pairs are } \\
\text { possible now? } \\
\text { 4. Draw these new number pairs together } \\
\text { with those you have already drawn. } \\
\text { 5. What happens if one of the numbers is } \\
9 \text { ? } \\
\text { 6. What happens with the drawing now? } \\
\text { 7. Find four new number pairs where one } \\
\text { of them is greater than } 9 \text {. Draw these } \\
\text { also. } \\
\text { 8. Discuss what you have found out. } \\
\text { Write down at least two points. }\end{array}$ \\
\hline Card 3 & & Card 4 \\
\hline$X+Y=$ & 12 & $2 X+Y=9$ \\
\hline & $\begin{array}{l}\text { Find a number pair that fits and } \\
\text { draw then in the same coordinate } \\
\text { system as before. }\end{array}$ & $\begin{array}{l}\text { 1. Find number pairs that fit and draw } \\
\text { these on a new piece of millimetre } \\
\text { paper. }\end{array}$ \\
\hline 2. & $\begin{array}{l}\text { How is this drawing in relation to } \\
\text { the first? }\end{array}$ & $\begin{array}{l}\text { Draw number pairs that fit the } \\
\text { expression } X+Y=7 \text { in this coordinate } \\
\text { system }\end{array}$ \\
\hline 4. & $\begin{array}{l}\text { Write these down. } \\
\text { Repeat the points above with the } \\
\text { expression: }\end{array}$ & $\begin{array}{l}\text { Find a number pair that fits both } \\
\text { expressions. What have you done } \\
\text { now? }\end{array}$ \\
\hline $\begin{array}{l}5 . \\
6 .\end{array}$ & $\begin{array}{l}X+Y=5 \\
\text { What do you see? Write it down. }\end{array}$ & $\begin{array}{l}\text { Can you write } 2 X+Y=9 \text { in a different } \\
\text { way such that it is easier to find the } \\
\text { number pairs that fit? }\end{array}$ \\
\hline
\end{tabular}

Workcards produced by Dronningens teachers following the "Special Planning Meeting" 